Saudi Journal of Humanities and Social Sciences

Abbreviated Key Title: Saudi J Humanities Soc Sci

ISSN 2415-6256 (Print) | ISSN 2415-6248 (Online)

Scholars Middle East Publishers, Dubai, United Arab Emirates

Journal homepage: https://saudijournals.com/sjhss

Original Research Article

\title{
An Analysis of Counter Insurgency in Maiduguri, Borno State, Nigeria: The Indirect Approach
}

\author{
Grace Egwu Ph.D ${ }^{1 *}$, Idris Mu'azu², Egwu Lisa Dumebi ${ }^{3}$ \\ ${ }^{1}$ Department of Sociology and Anthropology, Faculty of Social Sciences, University of Maiduguri, Nigeria \\ ${ }^{2}$ Department of Sociology and Anthropology, Faculty of Social Sciences, University of Maiduguri, Nigeria \\ ${ }^{3}$ No 6c Winston Churchill closes off Jimmy Carter St. Asokoro F.CT. Abuja, Nigeria
}

\begin{abstract}
DOI: $10.36348 /$ sjhss.2020.v05i03.004
| Received: 12.03.2020 | Accepted: 20.03.2020 | Published: 24.03.2020
\end{abstract}

*Corresponding author: Grace Egwu Ph. D

\section{Abstract}

Every youth in Maiduguri was suspected to be a member of the Boko Haram group by the Military, Youths who were not part of the Boko Haram ideology were viewed as infidels by the sect group. Hence, they were caught up in a cross road in between the Boko Haram group and the military. This situation informed the youth's resident in Hausari ward of Maiduguri to organize themselves into groups to fish out the members of Boko Haram and hand them over to the Military. The main objective of the study is to analyse the indirect approach of counter insurgency in Maiduguri, Borno State, Nigeria. The specific objectives are to assess the indirect approach of counter insurgency. And how such indirect approach in Nigeria by the military joint task force in collaboration with the Civilian joint task force in the North East has contributed in curbing insurgency, and also to assess the views of the community on the indirect approach of Civilian Joint Task Force in counter insurgency measures in Borno state. The study adopted Social Contract Theory as the theoretical framework for analysis. Thomas Hobbes noted that regulation can be accomplished if all civic enrol into an undertaken to give up their single ability to the supreme, in return for the care and protection of life and property. Simply put, that it is the obligation of the state to shield its citizens from danger. The resident in Borno state had hitherto surrendered their individual rights to the state and yet the state has not protected the people, hence the coming together of individuals to establish their own security organisation that is, the Civilian Joint Task Force in Maiduguri to bridle the activities of Boko Haram that has bedevilled the society. The data was obtained from primary and secondary sources. The primary sources derived from the questionnaire, while the secondary data were obtained from the review of relevant literatures. Purposive sampling techniques were used. One hundred and fifty (150) respondents constitute the sample size but only one hundred and forty six (146) were found suitable for the analysis. The questionnaire was administered in Bolori 1, Bolori 2, Bulablin, fezzan,Gamboru, Gwange 1, Gwange 2, Gwange 3, Hausari/zango, Lamisula, Jabba, Limanti, Mafoni, Maisandari, Shehuri North, Shehuri South. Sample was drawn from each cluster to represent the whole population of Maiduguri Metropolitan area. The researcher opted for this sample size given the nature of the study. The data was analysed using frequencies, tables and simple percentages. The data indicated that there is indirect engagement of the youths through the Youth Community Mobilization and volunteer groups in curbing insurgency in Maiduguri, Borno State. It also showed that the groups serve as local intelligence providing information to the arm forces. The youths have been instrumental in identifying and arresting suspected Boko Haram members and handing them over to the arm forces. The relationship between the arm forces and the volunteer groups is cordial in curbing insurgency in Maiduguri. The indirect approach is welcomed in Maiduguri and the members of the community believe that youth groups should be part of the security operations in Maiduguri Metropolis and the entire region bedevilled with insurgency. It is recommended that the federal and state government should encourage the youths who have been courageous in the fight against terrorism, by providing incentives and adequate logistics. This is to guarantee potency in their operation. To heighten the relationship between the arm forces and the Community mobilisation Task Force and the volunteer groups. There should be adequate legislative frame work for the procedure of mediate engagement of the topical in conflict resolution in form of vigilante groups.

Keywords: Analysis, Counter insurgency and Indirect Approach.

Copyright @ 2020: This is an open-access article distributed under the terms of the Creative Commons Attribution license which permits unrestricted use, distribution, and reproduction in any medium for non-commercial use (NonCommercial, or CC-BY-NC) provided the original author and source are credited. 


\section{INTRODUCTION}

Since September 112001 the world is experiencing a new pattern of irregular violent conflict in the form of terrorism and insurgency. The attacks by the Boko Haram terrorist group, otherwise called the Islamic State of West Africa (ISWA) in the North Eastern part of Nigeria since July 2009 has been sustained through the gun, bombs and suicide bombings, against the state Army and the civil society. More than one million people have been killed and ten thousand internally displaced from their homes [1]. In 2011 a Military Joint Task Force was established to rejuvenate law and order to the North eastern region. The Group includes of group of people who are willing to obey orders from the Nigerian Armed Forces, the Nigerian security agencies, the Department of State Security (D.S.S), the Nigerian Immigration and the Defence Intelligence Agency [2]. The responsibility of the task force was to stem the tide of insurgency in the state but ironically due to the gorilla style of engagement by the insurgent group, and the lack of knowledge of the terrain coupled with the mixing up of the enemy in the civilian population, the combined military forces of the Federal Government failed to bring the conflict to an end.

Every youth in Maiduguri was suspected to be a member of the Boko Haram group by the Military; Youths who were not part of the Boko Haram ideology were viewed as infidels by the sect group. Hence, they were caught up in a cross road in between the Boko Haram group and the military. This situation informed the youth's resident in Hausari ward of Maiduguri to organize themselves into groups to fish out the members of Boko Haram and hand them over to the Military. Thus fighting on the side lines of the federal troops there was a rebirth of the civilian joint task force and other vigilante groups. This indirect approach in combating the insurgents brought about a remarkable success in pushing the insurgent's out of Maiduguri, but the insurgents rather took their activities to villages and towns outside Maiduguri, The JTF destruction of the Boko Haram enclave at the sambisa forest has equally driven the sect members into the civilian populations at the Internally displaced peoples camp's (IDP) in towns and villages. It has been difficult to find the enemy in a guerilla style hide and seek tactics. The resilient group have prevented and hampered security and the achievement of developmental goals in Borno state and the Nigerian nation at large, Borno State and its environs has become the most dangerous state in Nigeria [3].

The frequent ambush of soldiers, kidnapping, abductions and suicide attacks on the civilian populations in a new wave of events, clearly shows the challenges in conventional style operations in countering insurgency in Borno state, thus a need to reexamine the indirect approach by other countries in counter insurgency that has caused human life and insecurity in many nations of the world. Surely the emergencies of counter terrorism in the contemporary world have in one way or the other mandated a new pattern of civil military relations that reflects the logic of' civilization of security $[4,5]$. The major increasing involvement of the civil society in counter terrorism operations and intelligence in the fight against Boko Haram is bolstered by the challenge posed by the Boko Haram group on the Nigerian state in the protection of communities from the on been slaughtered by the insurgency in the region.

The major factor amidst other factors responsible for the growth and spread of insurgency in the middle East, Asia, Africa and the North East of Nigeria in particular is similar and still remain, religious extremism and fundamentalism, which is enhanced by porous borders, lack of education, the internet and cyber communications.

Religious fundamentalism have its activities intricately interwoven, coordinated and connected with a common ideology of ousting all circular regimes and the establishment of Islamic states [6]. With armed groups like "The Islamic State of Iraq and Syria" (ISIS), Hezbollah, Al-Qaeda in the Islamic Maghreb (AQIM), Al-shaaban, Islamic State of West Africa (ISWA) formerly known as Jamaat Ahl as SunnahlidDa wahwal-Jihad, now popularly known as Boko Haram, whose members claim religious justification for their activities in places like Iraq, Sudan Darfur, Afghanistan, Pakistan, Israel, Palestine, Lebanon, Syria, Somalia, Mali and Nigeria. Nigeria, has not witnessed overt religious conflict, like the ongoing Boko Haram conflict. The Boko Haram group was established with the objective of the establishment of an Islamic state where a pure form of Islam can be practiced free from all western ideologies. The style of operation of insurgency in Pakistan, Somalia and Afghanistan is very similar to the activities of the Boko Haram group in Nigeria.

The Boko Haram conflict has left the North East of Nigeria in a state of fear and insecurity, while the emergence of the position has postulates an equally unconditional civil security response by the involvement of volunteer vigilantes in counter insurgency operations in Borno state. This significant huge development is the indirect approach to counter insurgency, the formation of the youth vigilantes group in Maiduguri otherwise known as civilian Joint Task Force was formed basically with a responsibility to identify, capture and hand over suspected terrorist members to the Military personnel for proper investigation. The volunteer vigilantes have proved to be a veritable and functional partner of the military in the fight against insurgency in the North East, with their understanding of the operational terrain of the area, the vigilantes have assisted the military in identifying and overriding important structures of the 
insurgents through local intelligence and reconnaissance. The formation of this group was premised on the basis that, every youth was suspected to be a member of Boko Haram [7]. The relative success of the civilian joint task force in line with the military in counter - insurgency in the North East of Nigeria affirms the underlying thinking in societal human security literature that security is best provided by the people and not for the people [8].

The locals can protect their own communities, because they are well acquainted with the terrain under which they operate, as against the troops who have no understanding of the language and terrain [8]. Hence the justification of the indirect approach in countering insurgency.

\section{Statement of the problem}

The Nigerian Government in the past ten years have tried to stop the activities of Boko Haram but all their efforts have become protracted but the fact still remains that Boko Haram activities have continued in the state and environs. Leaking of information by some of informant to the terror groups among the military personnel and civilians have contributed to one of the factors extending the activities of Boko Haram conflict and all effort made to improve the fight went in in vain due lack of trust and leaked of information among the security personnel. The Nigerian Government had virtually responded to the insurgency through appeals for foreign contribution to combat the local terrorism present by the group from France and other friendly nations around the world. The latest reaction of the Government under President Buhari regime demonstrated in the resettlement of the directives and control centre of the military to Maiduguri, this activity is pitched towards adding drift and revived dynamism to the military operation labelled as operation' Zaman Lafiya Dole' which is intend at delivering terrorism and insurgency to an end. Though so many has been written on the issues of education and Boko Haram, insurgency and the different alteration on peace and ways of ending the Boko Haram conflict, and the factors that have contributed to the emergence, increase and spread of Boko Haram, and the activities of the NGOS were adequately captured. There seems to be a dearth in literature relating to the indirect approach of counter insurgency.

\section{Objectives of the Study}

The objectives of the study is the assessment of the indirect approach of counter insurgency. And how such indirect approach in Nigeria by the military joint task force in collaboration with the Community mobilisers in the North Eastern Nigeria has contributed in curbing insurgency, and the assessment of the community views on the indirect approach of Civilian Joint Task Force in counter insurgency measures in Borno state.

\section{Theoretical Framework}

The study anchors on Social Contract Theory, For Thomas Hobbes directives which can be accomplish if all civic enter into an agreement to give up their individual powers to the dominant in return for the tribute of life and property. That simply means that it is the duty of the state to care and protect its citizens. For John Locke he suggested a contract that is based on "common interest"' the common interest depend on the merging once in a while of the whole egalitarian body, of every civic to reach a full agreement on how to live together. The resident in Borno state had hitherto surrendered their individual rights to the state and yet the state has not protected the people, hence the coming together of individuals to establish their own security organisation like (Vigilante groups) the Civilian Joint Task Force in Maiduguri to control the activities of Boko Haram that has bedevilled the society.

\section{METHODOLOGY}

One hundred and fifty (150) respondents constitute the sample size but only one hundred and forty six (146) were found suitable for the analysis. The questionnaire was administered in; Bolori 1, Bolori 2, Bulablin, fezzan,Gamboru, Gwange 1, Gwange 2, Gwange 3, Hausari/ zango, Lamisula, jabba, limanti, mafoni, maisandari, shehuri north, Shehuri south. Sample was drawn from each cluster to represent the whole population of Maiduguri Metropolitan Council. The researcher opted for this sample size given the nature of the study. The data collected through questionnaire was tabulated and analysed using frequencies, tables and simple percentages.

\section{DATA ANALYSIS AND PRESENTATION}

Table-1: Administered Questionnaires

\begin{tabular}{|l|c|c|}
\hline Questionnaires & $\begin{array}{l}\text { No. of } \\
\text { Respondents }\end{array}$ & Percentage (\%) \\
\hline Distributed & 150 & 100 \\
\hline Returned & 146 & 97 \\
\hline Not return & 4 & 03 \\
\hline
\end{tabular}

Source: Field Survey 2020

The table above shows that, out of one hundred and fifty (150) questionnaires administered, only one hundred and forty six (146) (97\%) of the respondents returned their questionnaires successfully. While 4 (3\%) did not return their questionnaires. Thus, the analysis was based on the one hundred and forty six (146) questionnaires generated.

Table-2: Gender of Respondents

\begin{tabular}{|l|c|c|}
\hline Gender & Frequency & Percentage (\%) \\
\hline Male & 79 & 54 \\
\hline Female & 67 & 46 \\
\hline Total & 146 & 100 \\
\hline \multicolumn{3}{|c|}{ Source: Field Survey 2020 }
\end{tabular}


The above table shows that $79(54 \%)$ of the respondents are male, while $67(46 \%)$ of the respondents are female. Therefore, most of the respondents are male.

Table-3: Age of Respondents

\begin{tabular}{|l|c|c|}
\hline Age Range & Frequency & Percentage (\%) \\
\hline $18-23$ & 24 & 16.4 \\
\hline $24-29$ & 44 & 30.1 \\
\hline $30-35$ & 38 & 26.0 \\
\hline 36 and above & 40 & 27.3 \\
\hline Total & 146 & 100 \\
\hline
\end{tabular}

Source: Field Survey 2020

Table 3 above indicates that $24(16.4 \%)$ of the respondents falls within the range 18-23 years, 44 $(30.1 \%)$ of the respondents falls within the range of 2429 years, $38(26.0 \%)$ of the respondents falls within the range of $30-35$ years of age and $40(27.3 \%)$ of the respondents falls within the range of 36 years and above. Therefore, most of the respondents fall within the range of 24-29 years.

Table-4: Marital Status of Respondents

\begin{tabular}{|l|c|c|}
\hline Marital Status & Frequency & Percentage (\%) \\
\hline Single & 72 & 49 \\
\hline Married & 68 & 47 \\
\hline Divorce & 01 & 01 \\
\hline Widow & 05 & 03 \\
\hline Total & 146 & 100 \\
\hline
\end{tabular}

Source: Field Survey, 2020

Table 4 above shows that $72(49 \%)$ of the respondents are singles, $68(47 \%)$ of the respondents are married, $1(1 \%)$ of the respondent is divorce and 5 $(3 \%)$ of the respondents are widow. Therefore, most of the respondents are married.

Table-5: Educational Attainment of the Respondents

\begin{tabular}{|l|c|c|}
\hline Educational Level & Frequency & Percentage (\%) \\
\hline No school & 01 & 01 \\
\hline Elementary school & 00 & 00 \\
\hline Secondary school & 14 & 10 \\
\hline NCE/HND & 88 & 60 \\
\hline First degree and above & 43 & 29 \\
\hline Total & 146 & 100 \\
\hline
\end{tabular}

Source: Field Survey, 2020.

Table 5 above shows 1 (1\%) of the respondent No school, $0(0 \%)$ elementary school, $14(10 \%)$ of the respondents are Secondary school leavers, 88 (60\%) of the respondents are NCE/HND holders and 43(29\%) of the respondents are first degree and above. Therefore, most of the respondents are NCE/HND holders.
Table-6: Occupation of Respondents

\begin{tabular}{|l|c|c|}
\hline Occupation & Frequency & Percentage (\%) \\
\hline Students & 44 & 30.1 \\
\hline Famers & 02 & 1.3 \\
\hline Traders & 09 & 6.1 \\
\hline Civil servants & 62 & 42 \\
\hline Professional & 11 & 08 \\
\hline Others & 18 & 12 \\
\hline Total & 146 & 100 \\
\hline \multicolumn{2}{|c|}{ Source: Field Survey, 2020 }
\end{tabular}

Table above shows that $44(30.1 \%)$ of the respondents are students, $2(1.3 \%)$ of the respondents are farmers, $9(6.1)$ of the respondents are traders, 62 $(42 \%)$ of the respondents are Civil servants, $11(8 \%)$ of the respondents are professionals and others 18 (12\%) of the respondents. Therefore, most of the respondents are civil servants.

Table-7: Portion Distribution of Respondents by Whether Vigilante and Civilian Joint Task Force Groups exist in their Community

\begin{tabular}{|l|c|c|}
\hline Response & Frequency & Percentage (\%) \\
\hline Yes & 143 & 98 \\
\hline No & 03 & 02 \\
\hline Total & 146 & 100 \\
\hline \multicolumn{3}{|c|}{ Source: Field Survey, 2020 }
\end{tabular}

Table 7 Shows that $143(98 \%)$ of the respondents affirmed that yes the groups exist in their community, while $3(2 \%)$ shows that vigilante and joint task force groups are not existing. Therefore, most respondents know the existence of groups in Maiduguri Metropolitan area.

Table-8: Percentage Probability of Respondents and the Acceptability of the Activities of Joint Task Force Vigilante and the Military in Maiduguri Borno State

\begin{tabular}{|l|c|c|}
\hline Response & Frequency & Percentage (\%) \\
\hline Yes & 144 & 99 \\
\hline No & 02 & 01 \\
\hline Total & 146 & 100 \\
\hline \multicolumn{3}{|c|}{ Source: Field Survey, 2020 }
\end{tabular}

The above table shows that 144 (99\%) of the respondents accept the activities of the Joint Task Force and Vigilante Groups in curbing insurgency in Maiduguri, Borno State, while $2(1 \%)$ do not accept their activities. Therefore, most respondents accept the activities of vigilante groups in Maiduguri Metropolitan Area.

This is in line with Eke [9] who pointed out that the common position towards the Bakassi Boys and other volunteer groups: people's permissiveness of volunteer groups is very high even among sensible people. 
Table-9: Distribution of Respondents by What the Joint Task Force and Vigilante Groups are Doing in their Community

\begin{tabular}{|l|c|c|}
\hline \multicolumn{1}{|c|}{ Response } & Frequency & Percentage (\%) \\
\hline $\begin{array}{l}\text { Curbing } \\
\text { Insurgency }\end{array}$ & 118 & 81 \\
\hline $\begin{array}{l}\text { Watching the } \\
\text { insurgents }\end{array}$ & 21 & 14 \\
\hline Don't Know & 07 & 05 \\
\hline Total & 146 & 100 \\
\hline
\end{tabular}

Source: Field Survey, 2020

Table above indicates that $118(81 \%)$ affirmed that the joint task force and vigilante group are curbing insurgency in Maiduguri Metropolitan Area, 21 (14\%) shows that the vigilante group are watching the insurgents in Maiduguri Metropolitan Area and 7 (5\%) clearly shows that they don't know. Based on the above table, majority of the respondents affirmed that the joint task force and vigilante groups are actively involved in curbing insurgency.

As observed by Burchard [10], blaming topical with shielding own residence becomes important, because they are well familiar with the location under which they control versus the scout groups bring in use who are not conversant with the terrain and language, and have little or no knowledge of the territory.

Table-10: Distribution of Respondents on Whether the Joint Task Force and Vigilante Groups Assist the Arm Forces in Curbing Insurgency in Maiduguri, Borno State

\begin{tabular}{|l|c|c|}
\hline Response & Frequency & Percentage (\%) \\
\hline Yes & 143 & 98 \\
\hline No & 03 & 02 \\
\hline Total & 146 & 100 \\
\hline \multicolumn{3}{|c|}{ Source: Field Survey, 2020}
\end{tabular}

Table 10 above shows that $143(98 \%)$ of the respondents agree that the civilian joint task force and vigilante groups assist the arm forces in curbing insurgency in $\mathrm{MMC}$, and $3(2 \%)$ of the respondents indicates that vigilante groups had not assist them or are not assisting them in curbing insurgency in Maiduguri.

Among this crisis, there was a powerful demand for the inclusion of the stricken groups in pursuance the Counter Insurgency agitates. The combatant demand the help of the civilian hunters to defend their territory and criminal inheritance from the bodily function of the Insurgents. Deposit on their friendly hope, the security personnel and different groups of vigilantes started coming together in an attempt to defeat and eliminate the common enemy Boko Haram [11].

Table-11: Distribution of Respondents on How the Groups Assist the Arm Forces in Curbing Insurgency in Maiduguri

\begin{tabular}{|l|c|c|}
\hline \multicolumn{1}{|c|}{ Response } & Frequency & Percentage (\%) \\
\hline $\begin{array}{l}\text { They serve as local } \\
\text { intelligence }\end{array}$ & 131 & 90 \\
\hline Don't know & 09 & 06 \\
\hline Total & 06 & 04 \\
\hline & 146 & 100 \\
\hline
\end{tabular}

Source: Field Survey, 2020

Table 11 above indicates that $131(90 \%)$ of the respondents affirmed that vigilante groups serves as local intelligence in assisting the arm forces. $9(6 \%)$ shows the vigilante are just hailing the arm forces 6 (4\%) of the respondents don't know how the vigilante assist in curbing insurgency in Maiduguri Metropolitan Area.

Suffice to note, therefore, that the emergence and involvement of Volunteer civilian joint vigilantes in the fight against insurgency in the North-East Nigeria was a child of necessity. Indeed, it is an existential struggle for survival in a hostile and volatile environment where the communities have resolved to rise up to the challenge of their time and collectively defend their destiny Anyadike [13].

Table-12 Distribution of Respondents on Which Ways Groups Assist the Arm Forces in Curbing Insurgency in Maiduguri, Borno State

\begin{tabular}{|l|c|c|}
\hline \multicolumn{1}{|c|}{ Response } & Frequency & Percentage (\%) \\
\hline Spying suspected Boko Haram & 12 & 08 \\
\hline Defending themselves only & 17 & 12 \\
\hline Arresting mistrusted Boko Haram members and handing them over to the arm forces & 117 & 80 \\
\hline Total & 146 & 100 \\
\hline
\end{tabular}

Source: Field Survey, 2020

Table 12 above shows that $12(8 \%)$ of the respondents point to spying on insurgents ways in which vigilante groups have helped in curbing insurgency, $17(12 \%)$ indicates that vigilante groups are only defending themselves and $117(80 \%)$ of the respondents affirmed that vigilante groups have helped by arresting Mistrusted Boko Haram members and handing taking them to appropriate authority for proper action to be taken. The vigilantes group gives information and hand over Boko Haram suspects to the security forces. Amnesty International [1]. 
Table-13: Distribution of Respondents on Whether Contribution of Joint Task Force and Vigilante Groups has helped in Curbing Insurgency in Maiduguri

\begin{tabular}{|l|c|c|}
\hline Responses & Frequency & Percentage (\%) \\
\hline Yes & 142 & 97 \\
\hline No & 4 & 3 \\
\hline Total & 146 & 100 \\
\hline \multicolumn{3}{|c|}{ Source: Field Survey, 2020 }
\end{tabular}

Table 13 indicates that $142(97 \%)$ of the respondents affirmed that the contribution of Local groups have helped in driving out the insurgents out of Maiduguri Metropolitan Area, while $4(3 \%)$ of the respondents think that the vigilante groups have not help in driving out the insurgents out of Maiduguri Metropolitan, Borno State.

Table-14: Distribution of Respondents on Whether the Arm Forces Alone can drive the Insurgents out of Maiduguri Metropolitan without the

Contributions of the Civilian Joint Task Force and

Vigilante Groups

\begin{tabular}{|l|c|c|}
\hline Responses & Frequency & Percentage (\%) \\
\hline Yes & 23 & 16 \\
\hline No & 123 & 84 \\
\hline Total & 146 & 100 \\
\hline \multicolumn{3}{|c|}{ Source: Field Survey, 2020 }
\end{tabular}

Table 14 above shows that $23(16 \%)$ of the respondents point to the arm forces alone driving insurgents out, while $123(84 \%)$ shows that the arm forces alone cannot drive the insurgents out of Maiduguri without the contribution of the vigilante groups.

Available literatures revealed that the rise of community mobilisers to fight against Boko Haram in the North-Eastern Nigeria was required by the demand for the civic to awareness and guard themselves among the seeming inability or bankruptcy of the government forces to insure their security. In this postulation, watch list (2014) revealed that "self-protection forces have become to many in North-Eastern Nigeria as civilians have taken arms against (Boko Haram) to protect their people and the communities which the find themselves, filling a security void left by the government security forces" (R:27).

Table-15: Distribution of Respondents on how often they see the Involvement of the Civilian Joint Task Force and Vigilante Groups Curbing Insurgency

\begin{tabular}{|l|c|c|}
\hline \multicolumn{1}{|c|}{ Responses } & Frequency & Percentage (\%) \\
\hline Daily & 121 & 83 \\
\hline once a week & 14 & 10 \\
\hline Once a month & 11 & 7 \\
\hline Total & 146 & 100 \\
\hline
\end{tabular}

Source: Field Survey, 2020
Table 15 above shows that 121 (83\%) being the highest proportion of the respondents see the groups daily curbing insurgency daily in their community, while $14(10 \%)$ of the respondents see vigilante groups once a week in their community and $11(7 \%)$ of the respondents see vigilante groups curbing insurgency in their community once a month.

Table-16: Percentage Share of Respondents on how Will they Rate their Response against the Insurgents

\begin{tabular}{|l|c|c|}
\hline Responses & Frequency & Percentage (\%) \\
\hline Quickly & 131 & 90 \\
\hline Slowly & 05 & 03 \\
\hline Don't know & 10 & 07 \\
\hline Total & 146 & 100 \\
\hline
\end{tabular}

Source: Field Survey, 2020

Table 16 above shows that 131 (90\%) being the highest proportion of respondents affirmed that groups respond against the insurgents quickly, 5 (3\%) of the respondents shows the respond slowly against the insurgents and $10(7 \%)$ of the respondent respondents indicate that they don't know.

Table-17: Distribution of Respondents on how will they Rate the Contributions of Civilian Joint Task Force and Vigilante Groups in Maiduguri

\begin{tabular}{|l|c|c|}
\hline Responses & Frequency & Percentage (\%) \\
\hline Excellent & 61 & 42 \\
\hline Very good & 69 & 47 \\
\hline Fair & 12 & 08 \\
\hline Poor & & 03 \\
\hline Total & 146 & 100 \\
\hline \multicolumn{2}{|c|}{ Source: Field Survey, 2020 }
\end{tabular}

The above table 17 indicates that $61(42 \%)$ of the respondents rates vigilante groups contributions as excellent, $69(47 \%)$ of the respondents rates vigilante groups contributions as very good, $12(8 \%)$ of the respondents rates their contributions as fair, and $4(3 \%)$ of the respondents rates their contributions as poor.

The findings above shows that $69(47 \%)$ majority of the respondents rate their contributions as very good.

Table-18: Percentage Distribution of Respondents on what Led to the Contributions of Vigilante Groups in Borno State

\begin{tabular}{|l|c|c|}
\hline Responses & Frequency & Percentage (\%) \\
\hline $\begin{array}{l}\text { Arm force } \\
\text { ineffectiveness }\end{array}$ & 80 & 55 \\
\hline $\begin{array}{l}\text { Lack of the presence } \\
\text { of the arm forces }\end{array}$ & 42 & 29 \\
\hline Don't know & 24 & 16 \\
\hline Total & 146 & 100 \\
\hline
\end{tabular}

Source: Field Survey, 2020 
Table 18 above shows that $80(55 \%)$ majority of the respondents thought what led to the contribution of the civilians in curbing insurgency in Maiduguri Metropolitan Area is arm forces ineffectiveness , 42 (28\%) lack of presence of the arm forces and $24(16 \%)$ don't know. What led to their contribution is the inability of security forces to take good care of civilians from Boko Haram attacks and the impairment of the security position, led to the emergence of local hunters for self-defence groups in North-East Nigeria, Human Right Council [13].

Table-19: Distribution of Respondents on the Relationship of Arm Forces and the Civilian Joint Task Force and Vigilante Groups in Borno State

\begin{tabular}{|l|c|c|}
\hline Responses & Frequency & Percentage (\%) \\
\hline Cordial & 134 & 92 \\
\hline Not Cordial & 12 & 8 \\
\hline Total & 146 & 100 \\
\hline \multicolumn{3}{|c|}{ Source: Field Survey, 2020 }
\end{tabular}

Table 19 above indicates that $134(92 \%)$ of the respondents assert that the relationship between the arm forces and the Civilian Joint Task Force, vigilante groups in curbing insurgency in Maiduguri Metropolitan Area is cordial. While 12 (8\%) affirmed that their relationship is not cordial. From the findings above shows that the highest proportion of the respondents assert that their relationship is cordial.

Table-20: Percentage Distribution of Respondents on Whether the Relationship between the Arm Forces and the Civilian Joint Task Force, Vigilante Groups has helped in Curbing Insurgency

\begin{tabular}{|l|c|c|}
\hline Responses & Frequency & Percentage (\%) \\
\hline Yes & 141 & 97 \\
\hline No & 05 & 03 \\
\hline Total & 146 & 100 \\
\hline \multicolumn{3}{|c|}{ Source: Field Survey, 2020 }
\end{tabular}

Table 20 above shows that 141 (97\%) the highest proportion of the respondents affirmed that the relationship between the arm forces and the vigilante groups has helped in curbing insurgency in Maiduguri Metropolitan Area. And 5 (3\%) show that their relationship has not help in curbing insurgency in Maiduguri Metropolitan Area. The Civilian joint task force (CJTF) led by the Nigerian army quickly realize the vigilantes, potential as a source of local knowledge, Intelligence and Man-power set out to help in curbing insurgency.

Table-21: Percentage distribution of Respondents in whether they have seen Vigilante Groups on checking points helping the Arm Forces

\begin{tabular}{|l|c|c|}
\hline Responses & Frequency & Percentage (\%) \\
\hline Yes & 136 & 93 \\
\hline No & 10 & 7 \\
\hline Total & 146 & 100 \\
\hline
\end{tabular}

Source: Field Survey, 2020
Table 21 above shows that $136(93 \%)$ of the respondents have seen vigilante groups at the checking points helping the arm forces by identifying Boko Haram suspected members. And $10(7 \%)$ of the respondents have not seen vigilante groups on investigating points and helping the arm forces in the fight against insurgency [12]. The Civilian Joint Task Force help the government forces with identifying, arresting and leaking Boko Haram suspects, controlling security checkpoints, providing information where it is necessary.

Table-22: Distribution of Respondents on the best Approaches of Curbing Insurgency

\begin{tabular}{|l|c|c|}
\hline \multicolumn{1}{|c|}{ Response } & Frequency & $\begin{array}{c}\text { Percentage } \\
(\%)\end{array}$ \\
\hline $\begin{array}{l}\text { Increase in number of } \\
\text { policemen }\end{array}$ & 13 & 9 \\
\hline $\begin{array}{l}\text { Increasing the activities } \\
\text { of the CJTF vigilante } \\
\text { group }\end{array}$ & 70 & 48 \\
\hline $\begin{array}{l}\text { Providing equipment to } \\
\text { the arm forces }\end{array}$ & 56 & 38 \\
\hline $\begin{array}{l}\text { Enhancing police } \\
\text { cooperation }\end{array}$ & 07 & 05 \\
\hline Total & 146 & 100 \\
\hline
\end{tabular}
Source: Field Survey, 2020

Table 22 above indicates that $13(9 \%)$ of the respondents views on the best way to curb insurgency in Nigeria today is by increasing the number of police men, $56(38 \%)$ of the respondents views is by providing equipment to the arm forces , $70(48 \%)$ being the majority of the respondents views is by increasing the number of Civilian Joint Task Force and vigilante, 7 $(5 \%)$ of the respondents views is by enhancing police co-operation Thus, the findings above shows that 70 $(48 \%)$ want an increase in the number civilian participation as an indirect way of curbing the Boko Haram conflict.

\section{Summary of Major findings}

The activities of the Civilian Joint Task Force and vigilante groups are acceptable as indirect complimentary efforts to stem the tide of insurgency in Maiduguri Metropolitan Area.

This is in line with Eke [9] assertion that", people's tolerance of vigilante groups is very high even among reasonable people',

The efforts of the indirect approach of the CJTF and Vigilante groups have been helpful in curbing insurgency in Maiduguri Metropolitan Area.

As observed by Burchard [10], engaging local hunters to check, prevent and protect their own communities become so important as this will help in reducing or even eradicate the menace of Boko Haram activities in Northern part of the country, because they 
are well conversant with the location under which they operate against the troops deployed who lack knowledge and the native language spoken around that axis, and lack knowledge of the terrain of operation.

Similarly, among this crisis, there was a powerful demand for the engagement of the touched communities in pursuance the counter-Insurgency campaign. The military used the assistance of the local hunters or ordinary civilians in form of security gathering and arrest to protect and defend their communities, from the menace of the Insurgents. Banking on their mutual good intention, the military and the joined efforts of the youths collaborating in an attempt to defeat their common enemy (Boko Haram Terrorist) [11]. Amnesty International (20 14, p. 12).

Vigilante groups have been seen daily curbing insurgency in Maiduguri Metropolitan Area. The relationship between the arm forces and the vigilante groups has been cordial in Maiduguri, Borno State.

The findings showed that the Civilian Joint Task Force and various vigilante groups have been effective in helping the military in curbing insurgency in Maiduguri Metropolitan Area.

Civilian Joint Task Force and Vigilante groups are everywhere and have been seen stop and search points helping the arm forces in Maiduguri [12]. The Civilian Joint Task Force and vigilante do regularly help the government forces with identifying, spying, leaking secret and arresting Boko Haram suspects, controlling security search points, providing information.

The relationship between the arm forces and the Civilian Joint Task Force vigilante groups has helped in curbing insurgency in Maiduguri Metropolitan Area. The Civilian Joint Task Force (CJTF) led by the Nigerian army quickly realize the youths participation as a, potential source of local knowledge, Intelligence and Man-power set out to help in curbing insurgency Human Right Council [13].

The study showed that the arm forces alone cannot send away the insurgents out of Maiduguri without the assistance rendered by the vigilantes group. Available literatures opined that the rise of anti-BokoHaram vigilantes in the North-Eastern Nigeria was postulated by the demand for the civilians to protect themselves among the clearly inability or failure of the government forces to ensure their security. In this sense, watch list (2014) revealed that "self-defence forces have become so wide in North-Eastern Nigeria as civilians have taken arms against (Boko Haram) to defend their people and the communities which they belongs, filling a security void left by the government security forces" (R:27).

\section{CONCLUSION}

Conclusively, the main objectives of this study was to examine the indirect approach to the declaration of the Boko Haram conflict. The participation and contribution of the youth vigilante groups in curbing insurgency in Maiduguri Metropolitan Council Area of Borno State. This is due to the ten years conflict that has claimed more than one million lives and displaced many in the North East of Nigeria particularly in Maiduguri Metropolitan Council. Thus, civilians and youth vigilante groups emerged to fill in the security gap.

The data collected indicated that there is indirect involvement of the youths through the Civilian Joint Task Force and vigilante groups in curbing insurgency in Maiduguri Metropolitan Area of Borno State. It also showed that the groups serve as local intelligence providing information to the arm forces. The youths have been instrumental in identifying and arresting suspected Boko Haram members and handing them over to the arm forces. The relationship between the arm forces and the vigilante groups is cordial in curbing insurgency in Maiduguri Metropolitan Area. The indirect approach is welcomed in Maiduguri Metropolitan Area and the members of the community believe that youth groups should be part of the security operations in Maiduguri Metropolitan Area and the entire region bedevilled with insurgency.

\section{RECOMMENDATIONS}

Based on these findings, the researcher made the following recommendations:

1. The indirect approach through youth participation in vigilante activities should be given priority to carryout out by well trained; able bodied persons enrol from the community to fight against insurgent group.

2. The Federal and State government should encourage the youths who have been courageous in the fight against terrorism. By providing incentives and adequate logistics. This is to ensure effectiveness in their operation.

3. To extend the mutual understanding between the arm forces and the Civilian Joint Task Force and the vigilante groups in the fight against insurgent.

4. There is need for ample opportunities for the members to frame work the operation of indirect participation of the local hunters in conflict resolution in form of vigilante groups to fight Boko Haram Insurgency.

5. Counter insurgency team collaborators should be well trained and well equipped in the aspects of fight against insurgent's detection and have the knowledge of the law. This is to enable and assist them to operate within the provision of the law governing domain of all existence.

6. There is need for the security relations to be set up at both State and Local Government level including development area (Villages) and that should also be 
headed by the Divisional Police Officer (D.P.O.). The committees or groups should organize constant secret conversation (meetings) to talk about security problems troubling their communities.

Finally, the researchers also suggested and recommends for further research be conducted or carryout on the indirect approach to combating insurgencies, Joint Police/Army Patrol and Law Enforcement Agencies in Nigeria.

\section{REFERENCES}

1. Amnesty International. (2014). Nigeria: More than 1,500 killed in armed conflict. In North- Eastern Nigeria in early 2014. London: Amnesty International Publication.

2. Raji, S., Ahmed, Y.D. (2013). Civilian Joint Task Force (CJTF) and Counter Insurgency Operation in Borno State, Nigeria. Journal of Sustainable Social and Management Sciences. www.mouau.edu.ng

3. Johnson, L. (1996). What is vigilantism? British Journal of criminology, 36, 220

4. Azarbajiani-Moghaddam, S., Wardak, M., Zaman, I., \& Taylor, A. (2008). Afghan hearts, Afghan Mind: Exploring Afghan perceptions of civilmilital7j relations (Executive summary and recommendations).

5. Horton, G. (2014). Conflict in Michoacán: Vigilante groups present challenges and opportunities for the Mexican Government. Michoacan: Wilson Center, Mexico Institute.

6. Adebayo, A.A. (2014). Impplication of Boko Haram Terrorism on National Development in Nigeria: A Critical View. Mediterranean Joural of Social Sciences, 5(16)
7. Ibekwe. (The Vanguard September 29, 2016)

8. Hassan, I. (n.d.). Counter Insurgency from below, the Need for Local Grassroots Defenders in Curbing the Insurgency in North-East Nigeria. Abuja: Center for Democracy and Development.

9. Eke, P.P. (2002). A review of HRWts and CLEEN!rs report: the legitimization of Murder and torture on state sponsored vigilante groups in Nigeria. Retrieved Nov. 212007 from http:// www.africaresourCe. Com/ content/ view! 35/ 6

10. Burchard, S.M. (2014). Democracy Trends in SubSaharan Africa, 1990 to 2014. Journal of Institute of Defense Analyses. 4850.

11. AOAV. (2012). the violent road: An overview of armed violence in Nigeria. London: Action on Armed Violence (AOAV)

12. Amnesty International. (2015). Stars on their Shoulders: Blood on their hands: War Crimes committed by the Nigerian military. London: Amnesty International Publication.6.Anyadike, O. (2014, August 11). Nigeria-the community turn.

13. Human Rights Council. (2015). September). Report of the United Nations High Commission for Human Rights violations and abuses committed by Boko Haram and their impact in human right in the affected countries. Geneva: Office of the United Nations High Commission for Human 'Rights.

14. Curbing Violence in Nigeria (II). (2014). The Boko Haram Insurgency Crisis Group Africa Report $\mathrm{N}^{\circ} 216,3,35-38$.

15. Watch, List. (2014). Who will care for us? Grave violations against. Children ainable Development in Nigeria. "Proceedings of the $A B U$ at 50 Wednesday Jan Uand, 17, 2018 Daily Trust. 